\title{
Türkiye su ürünleri yetiştiricilik politikalarının Avrupa Birliği Ortak Balıkçılık Politikası kapsamında SWOT analizi yöntemiyle değerlendirilmesi*
}

\section{Evaluating of Turkey aquaculture policy within the scope of the Common Fisheries Policy by SWOT analysis}

\author{
Simge ATAGÜL ÖZTÜRK ${ }^{1 \oplus}$, Serpil YILMAZ ${ }^{2}$ (D) \\ ${ }^{1}$ İstanbul Üniversitesi, Fen Bilimleri Enstitüsü, Su Ürünleri Yetiștiriciliği ve Hastalıkları ABD, İstanbul. \\ ${ }^{2}$ Akdeniz Üniversitesi, Su Ürünleri Fakültesi, Balıkçılık Temel Bilimler Bölümü, Antalya. \\ Sorumlu yazar (Corresponding author): S. Atagül Öztürk, e-posta (e-mail): simge.atagul@hotmail.com \\ Yazar(lar) e-posta (Author e-mail): serpilyilmaz @ akdeniz.edu.tr
}

\section{MAKALE BILGISİ}

Alınış tarihi 14 Eylül 2020

Düzeltilme tarihi 10 Aralık 2020

Kabul tarihi 11 Aralık 2020

\section{Anahtar Kelimeler:}

Ortak Balıkçılık Politikası

Su ürünleri yetiştiriciliği

Su ürünleri yetiştiriciliği politikaları

SWOT analizi

\begin{abstract}
ÖZ
Bu çalışmada Avrupa Birliği'nin 2014 yılında Ortak Balıkçılık Politikası'na yönelik getirmiş olduğu tüzük kapsamında yeniden düzenlenmiş olan mevzuat ve bunların uygulamaya olan yansımaları su ürünleri yetiștiriciliği özelinde incelenmiș, söz konusu düzenlemelerin ülkemizdeki su ürünleri yetiştiricilik politikaları ile karşılaştırılması yapılmıştır. Bu kapsamda inceleme sonucunda elde edilmiş veriler ışı̆̆ında SWOT Analizi yöntemi kullanılarak ülkemiz su ürünleri yetiştiricilik politikalarına ve sektöre olan yansımalarına dair objektif bir değerlendirme yapılmaya çalışılmıştır. Sektörün güçlü ve zayıf yönleri, firsat ve tehditler değerlendirilmiş ve sektörün gelişimine yönelik öneriler sunulmuştur.
\end{abstract}

\section{ARTICLE INFO}

Received 14 September 2020

Received in revised form 10 December 2020

Accepted 11 December 2020

Keywords:

Common Fisheries Policy

Aquaculture

Aquaculture policies

SWOT analysis

\begin{abstract}
Common Fisheries Policy has been updated several times as a result of reforms and the most recent of which took effect on 2014. In this study, new regulations on Common Fisheries Policy are reviewed and compared with the current aquaculture policy in Turkey and evaluated of the impact of new regulations on the aquaculture sector in Turkey. As a result of the research tried to make an objective assessment for Turkey aquaculture policy and industry by SWOT analysis method and determine strong weaknesses, opportunities and threats. It was aimed to make suggestions on Turkey's aquaculture sector development in the light of the obtained information.
\end{abstract}

*Bu araştırma Simge Atagül Öztürk tarafindan 27.06.2019 tarihinde sunulmuş olan ‘Türkiye ve Avrupa Birliği’nde Uygulanmakta Olan Su Ürünleri Yetiştiricilik Politikaları'nın Karșılaştırmalı Analizi’ başlıklı yüksek lisans tezinden üretilmiștir.

\section{Giriş}

Avrupa Birliği (AB) dünyadaki en önemli su ürünleri üreticilerinden biri konumundadır. Nitekim, Çizelge 1'de verilmiş olan 2016 yılı dünya su ürünleri üretim miktarlarına göre AB; Çin, Endonezya, Hindistan ve Vietnam'ın ardından 5. sırada yer almaktadır. Söz konusu üretimin yaklaşık \%20'lik kısmı yetiştiricilik yoluyla elde edilmiştir. AB önemli üreticilerden biri olmasının yanı sira aynı zamanda 2016 yılı için kayıtlara geçmiş olan 54.3 milyon avroluk değer ile de su ürünleri yetiştiricilik ürünlerinin dünyadaki en yüksek ticaret akışlarından bir tanesine sahiptir (EU Market Report 2018).

$\mathrm{AB}$ ülkelerinde su ürünleri tüketimi de oldukça yüksektir ve $\mathrm{AB}$ bu talebi karşılayabilmek adına su ürünleri ithal etmek zorunda kalmaktadır. Bugün AB'nin iç pazarında tüketilmekte olan balığın \%60'1 farklı ülkelerden ithal edilmektedir (European Commission 2016). Bu nedenle AB, yetiştiricilik sektörüne yönelik gerekli düzenlemeleri ve yatırımları yaparak ithal balığa olan bu ihtiyacı düşürmeye çalışmaktadır. Ayrıca yetiştiriciliğin geliştirilmesi, AB'de kırsal bölgelerde kalkınmaya ve sosyal yapıya sağlayacağı katkı açısından da çok önemli görülmektedir. Yetiştiriciliğin gelişmesine yönelik yeni düzenlemeler Ortak Balıkçılık Politikası (OBP)'na yapılmış olan son reformunda da önemli başlıklarından bir tanesini oluşturmaktadır. 
OBP resmi oluşumundan itibaren (1983) yıllar içerisinde önemli reformlara uğramış ve sektörü her yönü ile ele almaya yönelik bir kapsam oluşturmayı hedeflemiştir. Nitekim 2014 yılı itibariyle uygulanmaya başlanmış olan yeni tüzükle birlikte $\mathrm{AB}$, denizler ve balıkçılık için daha iyi bir geleceğin koşullarını ve onları destekleyen sağlıklı bir deniz ortamını ortaya koymayı amaçlamaktadır (European Commission 2011).

Ülkemizde 1970'li yıllarda başlayan su ürünleri yetiştiriciliği miktarı üretimin başladığı ilk günden günümüze kadar önemli bir artış göstermiştir. TÜİK verilerine göre araştırmanın yapıldığı 2017 yılı itibariyle su ürünleri üretim miktarı 630820 ton olarak kayıtlara geçmiş ve bu üretim miktarı ile bir önceki yıla göre \% 7.2'lik bir büyüme gerçekleştirilmiştir (TÜIKK 2019). Türkiye, Çizelge 2'de görüldügü gibi dünya levrek yetiştiriciliğinde $\mathrm{AB}$ Ülkelerinden sonra ikinci büyük üretici konumundadır ve $A B$ 'nin levrek ithalatındaki en büyük tedarikçisidir. Nitekim AB'nin birlik dişından ithal ettiği levreğin neredeyse tamamı Türkiye'den temin edilmektedir (EUMOFA 2019). AB tarafindan sektöre yönelik yayınlanmış olan son raporlarda da Türkiye'nin $\mathrm{AB}$ pazarında gün geçtikçe daha da etkili olduğu gözlenmektedir. AB'nin güncel ithalat ve ihracat rakamlarına göre Türkiye'nin bu anlamada rakibi olan birlik üyesi Yunanistan'in son yıllarda Kuzey Avrupa pazarlarına ihracat ettiği çipura ve levrek miktarlarında gerilemeler yaşanmaktadır. 2010-2016 yılları arasında İngiltere'ye ihraç edilen ürün miktarı 4639 tondan \%44 bir düşüş ile 2621 tona gerilemiş̧ir. Almanya içinse bu rakam yaklaşık \%8'lik bir gerileme ile 2993 tondan 2757 tona düşmüştür. Aynı dönem içinde Türkiye'nin İngiltere'ye olan ihracatı ise 33 tondan 1735 tona, Almanya için ise 61 tondan 4553 tona yükselerek önemli bir artış göstermiştir. Türkiye'nin gittikçe genişlediği bir başka gelişmekte olan pazar ise Hollanda'dır. Ülkemizin Hollanda'ya olan ihracat hacmi 2010 y1lında 2003 ton iken 2016 yılında 7619 tona yükselmiştir (EU Market Report 2018). Ancak tüm bu olumlu tabloya rağmen Türkiye'nin su ürünleri yetiştiricilik sektöründe daha da güçlü rekabet edebilmesi için bazı teşviklere ihtiyacı olduğu söylenebilir. Bu nedenle yetiştiricilik sektörüne yönelik bu tür araştırma ve değerlendirmeler büyük önem taşımaktadır. Çünkü OBP gerek kendi sektörünün gelişmesine yönelik getirdiği düzenlemeler gerekse tüm dünyaca kabul gören standartlarıyla Ülkemiz açısından da önemli bir yapılanmadır.

Bu çalışmada 2014 yılında yürürlüğe girmiş olan OBP'nin güncel mevzuatlarını yetiştiricilik özelinde genel hatlarıyla inceleyerek, SWOT analizi yöntemi ile ülkemiz yetiştiricilik sektörüne yönelik bir değerlendirme yapılmıştır.

Çizelge 1. 2016 yılı dünya su ürünleri üretim miktarları (1000 ton) (EU Market Report 2018).

Table 1. World production of fisheries and aquaculture in 2016 (1000 tonnes) (EU Market Report 2018).

\begin{tabular}{lcccc}
\hline & Avcllk & Su Ürünleri Yetiştiriciliği & Toplam Üretim & Oran $(\%)$ \\
\hline Çin & 17807 & 63722 & 81529 & 41 \\
Endonezya & 6584 & 16616 & 23200 & 12 \\
Hindistan & 5082 & 5703 & 10785 & 5 \\
Vietnam & 2786 & 3635 & 6421 & 3 \\
AB (28) & 5014 & 1290 & 6304 & 3 \\
ABD & 4931 & 444 & 5375 & 3 \\
Rusya & 4773 & 174 & 4947 & 2 \\
Japonya & 3275 & 1068 & 4343 & 2 \\
Filipinler & 2028 & 2201 & 4229 & 2 \\
Peru & 3812 & 100 & 3912 & 2 \\
Bangladeş & 1675 & 2204 & 3879 & 2 \\
Norveç & 2203 & 1326 & 3529 & 2 \\
Güney Kore & 1396 & 1859 & 3255 & 2 \\
Myanmar & 2072 & 1018 & 3090 & 2879 \\
Şili & 1829 & 1050 & 2494 & 1 \\
Tayland & 1531 & 963 & 30181 & 1 \\
Diğer & 23347 & 6834 & 200352 & 100 \\
Toplam & 90145 & 110207 & & 2 \\
\hline
\end{tabular}

Çizelge 2. 2007-2016 yılları arası dünya deniz levreği yetiştiricilik üretim miktarı(ton) (EUMOFA 2019).

Table 2. World production amount of sea bass aquaculture between 2007-2016 (tonnes) (EUMOFA 2019).

\begin{tabular}{lrrrrrrrrrr}
\hline \multicolumn{1}{c}{ Y1llar } & 2007 & \multicolumn{1}{c}{2008} & 2009 & 2010 & 2011 & 2012 & 2013 & 2014 & 2015 & 2016 \\
\hline AB 28 & 60494 & 60443 & 58656 & 65180 & 69052 & 63929 & 63875 & 62825 & 69763 & 81852 \\
Türkiye & 41900 & 49270 & 46554 & 50796 & 47013 & 65512 & 67913 & 74653 & 75164 & 80847 \\
Misır & 589 & 4383 & 5381 & 16306 & 17714 & 13798 & 12328 & 15167 & 14343 & 24498 \\
Tunus & 793 & 788 & 1370 & 1466 & 2832 & 1999 & 1968 & 1869 & 2802 & 2564 \\
Diğer & 689 & 570 & 571 & 580 & 665 & 784 & 687 & 840 & 1059 & 1243 \\
Toplam & 104465 & 115454 & 112532 & 134328 & 137276 & 146022 & 146771 & 155354 & 163131 & 191004 \\
\hline
\end{tabular}




\section{Materyal ve Metot}

Araştırmanın ana materyalini, AB'de 2014 yılı ile itibariyle birlik içerisinde uygulamaya başlamış olan yeni OBP ve Türkiye'deki yetiştiricilikle ilgili mevzuat ile konu hakkında yapılmış olan çeşitli literatür araştırmaları oluşturmaktadır. Bu kapsamda konuyla ilgili yayınlanmış makale, rapor ve istatistiklerden de yararlanılmış, birincil veriler ise yurtiçi ve yurtdışında ilgili kurumlar ile çeşitli görüşmeler yapılarak elde edilmiş, T.C. Tarım ve Orman Bakanlığı bünyesinde yer alan Balıkçılık ve Su Ürünleri Genel Müdürlüğü ile $\mathrm{AB}$ Komisyonu bilgisayar kayıtları ile yayınlarından ve faaliyet raporlarından faydalanılmıştır.

\section{Bulgular ve Tartışma}

\subsection{Avrupa Birliği OBP kapsamında su ürünleri yetiştiricilik politikalarl}

AB'de su ürünleri yetiştiriciliği kıyı topluluklarında sürdürülebilir ekonomik büyümeyi desteklemek açısından önemli bir ekonomik faaliyet olarak görülmektedir. $\mathrm{Bu}$ kapsamda yetiştiriciliğin sürdürülebilirliği amacıyla; ürünlerin kalite ve güvenliğinin, endüstrinin potansiyelini ortaya çıkarmak ve rekabet gücünü artırmak için önemli bir faktör olduğu düşünülmektedir. $\mathrm{Bu}$ nedenle $\mathrm{AB}$, araştırma ve teknolojileri destekleyici, erişim ve idari engeller ile ilgili mevcut sorunların üstesinden gelmeyi mümkün kılacak, sürdürülebilir ve rekabetçi bir su ürünleri yetiştiriciliğini teşvik etmek istemektedir (European Commission 2013). Sektörün geliştirilmesine yönelik düzenlemeler, kontrol mekanizmasından, üretimin ve pazarlama sürecinin planlamasına, örgütlenme modellerinden, finansal desteklere ve istikrarlı bir piyasa oluşturmaya yönelik oldukça kapsamlı şekilde ele alınmış olan bir plan dahilinde yürütülmektedir. Söz konusu plan dahilindeki tüm unsurlar AB'de 1 Ocak 2014 tarihi itibariyle uygulamaya konulan 1380/2013 AB sayılı Ortak Balıkçılık Politikası tüzüğü kapsamında ayrıntılı şekilde ele alınmaktadır. Söz konusu tüzük kapsamında OBP; Koruma ve Kontrol politikası, Yapısal Politika, Ortak Piyasa Düzeni ve Uluslararası İlişkiler olmak üzere dört temel politikadan oluşmaktadır (EU Regulation 2014a).

Sektörün gelişmesine yönelik en önemli başlıklardan bir tanesi finansman desteğidir. AB geçmişten beri OBP'sının yapısal politikası kapsamında sektörün desteklenmesine yönelik çeşitli fonlar oluşturmuştur. Bu fonların sonuncusu yeni reform kapsamında oluşturulmuş olan Avrupa Denizcilik ve Balıkçılık Fonu (EMFF)'dur (European Commission 2014a). EMFF, 2014-2020 yılları arası için oluşturulmuş bir fon olup 6.4 milyar avroluk toplam bütçeye sahiptir. $\mathrm{AB}$ komisyonu bu bütçenin yaklaşık olarak \%21'ni sürdürülebilir su ürünleri yetiştiriciliğine ayırmıştır. EMFF kapsamında üye devletlere sağlanacak olan destek tutarının belirlenmesinde sektörde çalışan kişi sayısı, üretim kapasitesi, denetleme kapasitesinin durumu, ihtiyacının büyüklüğ̈̈ gibi birçok farklı kriterler göz önüne alınmaktadır (EU Regulation 2013). Yetiştiricilik için destek kapsamını oluşturan başlıkların bazıları; yetiştiriciliğin çeşitlendirilmesine yönelik yatırımlar, çalışma ve güvenlik koşullarının iyileştirilmesi, işletmelerin modernizasyonu, enerji ve kaynak verimliliğini artıracak yatırımlar ile çevresel etkilerin azaltılmasına yönelik çalışmalar şeklinde özetlenebilir (EU Regulation 2014b).

OBP'nın sektöre yönelik bir diğer önemli unsuru ise kontrol mekanizmasını düzenleyen koruma ve kontrol politikasıdır. Bu başlık ağırlıklı olarak denizel sisteme ve avcılı̆̆ın k1sitlanmasına yönelik olmakla beraber denizden sofraya tüm sürecin izlenmesi ve kontrolüne dair yaptırımlar yetiştiricilik ürünleri için de aynı şekilde geçerlidir. Birlik içerisindeki tüm gıda maddelerinde olduğu gibi, su ürünleri yetiştiricilik ürünlerinin tüm üretim süreçlerinde de temel izlenebilirlik prosedürü uygulanmak zorundadır (EU Regulation 2002).

OBP'nın en kapsamlı ve önemli bir diğer politikası ise piyasanın düzenlenmesine yönelik olarak oluşturulmuş Ortak Piyasa Düzeni'dir (OPD). OBP'na 2014 yılında yapılan reformla birlikte OPD'ne yönelik de yeni bir tüzük getirilmiştir. Yeni tüzük kapsamında güncellenen OPD, profesyonel örgütlenmeler, ortak pazarlama standartları, tüketici bilgisi, rekabet kuralları ve pazar bilgisi olmak üzere beş temel unsurdan oluşmaktadır (EU Regulation 2013). OPD'ne yönelik getirilen söz konusu yeni tüzük ile piyasaların şeffaflığının geliştirilmesi ve rekabet gücünün artırılması hedeflenmektedir (European Commission 2014a).

Profesyonel örgütlenmeler altında yer alan üretici örgütleri AB'de sektörün bel kemiği durumundadırlar. OPD tüzüğü altında görev, yetki ve sorumlulukları ayrıntılı olarak belirlenmiş olan üretici örgütleri aktif bir role sahiptirler. Son tüzükle beraber üretici örgütlerine üretim ve pazarlama planları yapma zorunluluğu getirilmiştir. Bu planlar yetiştirilen türler için bir üretim programı, pazarlama stratejisi, arz miktarının ayarlanmasına yönelik alınacak tedbirleri ve kuralları ihlal eden üyelere yönelik cezai yaptırımları içermekte olup, OPD'nin hedeflerine ulaşmasında çok önemli bir araç olarak görülmektedirler (EU Regulation 2013).

Yeni tüzük kapsamında getirilen bir diğer önemli unsur ise genişletilmiş tüketici bilgilendirmesi başlığıdır. Bir önceki tüzükte de yer alan bu başlık yeni tüzükle beraber daha kapsamlı bir hale getirilmiştir. $\mathrm{AB}$ komisyonu genişletilmiş hükümler ile tüketicilerin bilinçli satın alma seçimleri yapmalarını sağlamayı hedeflemektedir (European Commission 2014b). Bu tüzüğe göre, birlik içerisinde pazarlanan yetiştiricilik ürünleri, menşelerinden veya pazarlama yöntemlerinden bağımsız olarak sadece uygun markalama ve etiketlemeye sahip ise nihai tüketiciye veya toptan gida dağıtım şirketine satışa sunulabilmektedirler (EU Regulation 2013). Bu durum $\mathrm{AB}$ pazarında yer alacak ithal ürünler için de aynı şekilde geçerlidir.

Yeni tüzükle beraber getirilen bir diğer düzenleme ise rekabet kuralları ve pazar bilgisi başlıklarıdır. Yeni OPD tüzüğü kapsamında $\mathrm{AB}$ içerisindeki avcılık ve yetiştiricilik pazarına yönelik tüm bilgilerin paydaşlar arasında paylaşılması amacıyla "pazar bilgisi" başlığı altında yeni bir düzenleme getirilmiştir. $\mathrm{Bu}$ amaç doğrultusunda Avrupa Komisyonu, Balıç̧ılık ve Su Ürünleri Yetiştiriciliği Ürünleri Avrupa Piyasa Gözlemevi'ni (EUMOFA) kurmuştur. EUMOFA Avrupa Komisyonu tarafından piyasa istihbaratını geliştirmek, avcılık ve yetiştiricilik için pazarın şeffaflığına ve verimliliğine katkıda bulunmak amacıyla geliştirilmiş çevrimiçi bir araçtır ve temel hedefi avcılık ve yetiştiricilik ürünleri için $A B$ pazarında güvenilir bilgi sağlamaya yöneliktir (European Commission 2011). Yine yeni OPD'nin unsurlarından birini oluşturan rekabet kurallarının düzenlemeleri gereğince Avrupa Birliği'nin İşleyişine Dair Antlaşma (TFEU)'nın 10'den 106'ya kadar olan maddeleri ve bunların uygulama hükümleri ile ilgili TFEU'nun 101(1). ve 102. maddelerinde belirtilen ticari anlaşmalara, kararlara ve uygulamalara yönelik olan rekabet kuralları, avcılık ve yetiştiricilik ürünlerini de aynı şekilde kapsamaktadır (EU Regulation 2013). Yürürlüğe giren yeni uygulamalar 
kapsamında, değişmeden eski tüzükteki şekliyle kalan tek başlık ise ortak piyasa standartları başlığıdır. Bu başlık kapsamında ilgili tüzükte ayrıntılı olarak verilen tazelik ve boyut standartlarına uymayan hiçbir ürünün $\mathrm{AB}$ pazarında sunulması söz konusu olamamaktadır.

\subsection{Türkiye su ürünleri yetiştiricilik politikalarının $O B P$ kapsamında değerlendirilmesi}

Ülkemizde su ürünlerine yönelik düzenlemeler 1380 sayılı Su Ürünleri Kanunu kapsamında düzenlenmektedir. Söz konusu kanunun genel kapsam ve içeriğini su ürünlerinin üretimi, korunması ve kontrolüne dair çeşitli hükümler oluşturmaktadır (Su Ürünleri Kanunu 1971). Ancak ülkemizde su ürünlerinin düzenlenmesin de bir çok farklı kanun ve yönetmelik de söz konusudur. $\mathrm{Bu}$ anlamda OBP ve 1380 sayılı çerçeve kanun, oldukça farklı iki yapılanma olarak karşımıza çıkmaktadır. Ancak AB'deki OBP içeriği ve kapsamı göze alındığında 1380 sayılı kanunun kapsamının oldukça sınırlı kaldığı söylenebilir.

Ülkemizdeki su ürünleri yetiştiricilik miktarları yıllar içerisinde devamlı bir artış göstermiştir. Söz konusu olumlu tablonun su ürünleri dış ticareti için de geçerli olduğu bilinmektedir. Çizelge 3'de Türkiye'nin 2008-2018 y1lları arasındaki su ürünleri ihracat-ithalat miktar ve değerleri verilmektedir. Çizelge 3'de görüldüğü gibi Türkiye'nin 2018 y1lındaki su ürünleri ihracatı 177539 ton iken su ürünleri ithalatı ise 98314 ton olarak gerçekleşmiştir. Aynı yıl içerisinde en yüksek ihracatın gerçekleştiği ilk 10 ülkenin yedisini ise $\mathrm{AB}$ ülkeleri oluşturmaktadır (TÜIK 2019).

Sektörde yıllar içerisinde yaşanmış olan bu büyümede yeni teknolojilerin sektöre etkisi, sahip olunan eğitimli iş gücü, Türkiye'nin su ürünleri yetiştiriciliği açısından coğrafi avantajı gibi konuların yanı sıra yıllardır sektöre yönelik yapılmış olan desteklerin payı büyüktür. Ülkemizde su ürünlerine yönelik desteklemeler ilk olarak 2003 yılında çupra, levrek ve alabalık işletmelerine yönelik olarak yapılmıştır (Çavdar 2009). Desteklerin verilmeye başlandığı yıldan günümüze kadar, desteklerin miktarları ve çeşitleri giderek artmış, başlangıçta yetiştiricilikteki ana türlere yönelik olan destekler, bugün birçok yeni türü de kapsamına almıştır. Bugün su ürünleri yetiştiricilerinin faydalanabildiği bu devlet desteklerinin her biri farklı kanun ya da yönetmeliklere göre düzenlenmektedir. Bu kapsamda söz konusu destekler; 'Su Ürünleri Yetiştiriciliği Destekleme Tebliği (2018)'ne göre düzenlenmekte olan Üretim
Desteği, 'Su Ürünleri Yetiştiriciliğinde İyi Tarım Uygulamaları Destekleme Ödemesi Yapılmasına Dair Tebliğ (2019)'e göre düzenlenmekte olan İyi Tarım Uygulamaları Desteği, Tarım ve Kırsal Kalkınmayı Destekleme Kurumu (TKDK) tarafindan kırsal kalkınma kapsamında su ürünleri yetiştiriciliğine yönelik verilen destekler (TKDK 2019), 'T.C Ziraat Bankası A.Ş. ve Tarım Kredi Kooperatiflerince Tarımsal Üretime Dair Düşük Faizli Yatırım ve İşletme Kredisi Kullandırılmasına İlişkin Uygulama Esasları Tebliği (2018)'e göre düzenlenen İndirimli Krediler ve '5363 sayıl1 Tarım Sigortaları Kanunu (2005)'na göre düzenlenen $\mathrm{Su}$ Ürünleri Sigortası şeklinde sıralanabilir. Yetiştiricilik sektörüne sağlanmakta olan mali destekler açısından $\mathrm{AB}$ ve Türkiye'ye bakıldığında farklı uygulamalar karşımıza çıkmaktadır. Yukarıda bahsedildiği üzere ülkemizde sektöre yönelik verilmekte olan desteklerin her biri farklı yönetmelikler altında yer almaktadır. Oysa AB'nin EMFF'si incelendiğinde sektöre yönelik desteklemelerin bütünsel bir anlayışla, birçok farklı alana yönelik olarak ve tek bir düzenleme altında ele alındığı görülmektedir. Ülkemizde devlet desteklerine yönelik yönetmelikler incelendiğinde ise desteğin ağırlıklı olarak üretime yönelik olduğu görülmektedir.

$\mathrm{AB}$ 'de su ürünleri yetiştiricilik ürünlerine temel düzeyde bir izlenebilirlik prosedürü uygulanması zorunludur. Ülkemizdeki yetiştiricilik ürünleri için de benzer şekilde işleyen bir kontrol mekanizmasından söz etmek mümkündür. $\mathrm{Bu}$ kapsamda $\mathrm{AB}$ müktesebatına uygun olarak hazırlanmış olan '5996 sayılı Veteriner Hizmetleri, Bitki Sağlığı, Gıda ve Yem Kanunu (2010)' na göre tüm avcılık ve yetiştiricilik ürünleri temel izlenebilirlik prosedürüne tabidirler. Ancak daha önce de belirtildiği gibi, OBP ülkemizdeki mevcut uygulamalardan oldukça farklı bir yapılanmadır. AB'de OPD tüzüğü altından düzenlenmekte olan örgütlenme modelleri, ortak standartlar, pazar rekabetine ve kurallarına yönelik düzenlemeler, ülkemizde tek bir çatı altında toplanmış bir düzenlemeye sahip değildirler. Nitekim Ülkemizde su ürünleri yetiştiriciliğine dair örgütlenme modelleri incelendiğinde karşımıza Kooperatifler ve Üretici Birlikleri yapılanmaları çıkmaktadır. Bu iki yapılanma da su ürünleri özelinde hazırlanmış düzenlemeler olmayıp tüm kooperatifleri ve üretici birliklerini kapsamaktadır. İlgili kanunların genel içerikleri ağırlıklı olarak üyelik şartlarını ve kooperatif ve birliğin ortaklık koşullarına yönelik usulleri belirlemektedirler (Tarımsal Üretici Birlikleri Kanunu 2004), (Kooperatifler Kanunu 1969). Özellikle AB'deki su ürünleri

Çizelge 3. 2008-2018 yılları arasındaki su ürünleri ihracat-ithalat miktar ve değerleri.

Table 3. Turkey aquacultural export-import amounts and values, 2008-2018.

\begin{tabular}{|c|c|c|c|c|c|c|c|c|c|c|}
\hline \multirow[b]{2}{*}{ YILLAR } & \multicolumn{5}{|c|}{ İHRACAT-İTHALAT MİKTARLARI (TON) } & \multicolumn{5}{|c|}{ İHRACAT-İTHALAT DEĞERLERİ (USD) } \\
\hline & $\begin{array}{c}\text { İhracat } \\
\text { Miktar (ton) }\end{array}$ & $\begin{array}{c}\text { İthalat } \\
\text { Miktar (ton) }\end{array}$ & $\begin{array}{c}\text { Toplam } \\
\text { Miktar (ton) }\end{array}$ & $\begin{array}{l}\text { İhracat } \\
\% \text { Oran }\end{array}$ & $\begin{array}{l}\text { İthalat } \\
\% \text { Oran }\end{array}$ & $\begin{array}{c}\text { İhracat Değer } \\
\text { (USD) }\end{array}$ & $\begin{array}{l}\text { İthalat Değer } \\
\text { (USD) }\end{array}$ & $\begin{array}{l}\text { Toplam Değer } \\
\text { (USD) }\end{array}$ & $\begin{array}{l}\text { İhracat } \\
\% \text { Oran }\end{array}$ & $\begin{array}{l}\text { İthalat } \% \\
\text { Oran }\end{array}$ \\
\hline 2008 & 54526 & 63222 & 117748 & 46.31 & 53.69 & 383297348 & 119768842 & 503066190 & 76.19 & 23.81 \\
\hline 2009 & 54354 & 72686 & 127040 & 42.78 & 57.22 & 318063028 & 105822852 & 423885880 & 75.04 & 24.96 \\
\hline 2010 & 55109 & 80726 & 135835 & 40.57 & 59.43 & 312935016 & 133829563 & 446764579 & 70.04 & 29.96 \\
\hline 2011 & 66738 & 65698 & 132436 & 50.39 & 49.61 & 395306914 & 173886517 & 569193431 & 69.45 & 30.55 \\
\hline 2012 & 74006 & 65384 & 139390 & 53.09 & 46.91 & 413917190 & 176402894 & 590320084 & 70.12 & 29.88 \\
\hline 2013 & 101063 & 67530 & 168593 & 59.94 & 40.06 & 568207316 & 188068388 & 756275704 & 75.13 & 24.87 \\
\hline 2014 & 115381 & 77551 & 192932 & 59.80 & 40.20 & 675844523 & 198273838 & 874118361 & 77.32 & 22.68 \\
\hline 2015 & 121053 & 110761 & 231814 & 52.22 & 47.78 & 692220595 & 250969660 & 943190255 & 73.39 & 26.61 \\
\hline 2016 & 145469 & 82074 & 227543 & 63.93 & 36.07 & 790303664 & 180753629 & 971057293 & 81.39 & 18.61 \\
\hline 2017 & 156618 & 100444 & 257062 & 60.93 & 39.07 & 854731829 & 230111248 & 1084843077 & 78.79 & 21.21 \\
\hline 2018 & 177539 & 98314 & 275853 & 64.36 & 35.64 & 952001252 & 188951045 & 1140952297 & 83.44 & 16.56 \\
\hline Toplam & 1121856 & 884390 & 2006246 & & & 6356828675 & 1946838476 & 8303667151 & & \\
\hline
\end{tabular}


üretici örgütlerinin pazar fonksiyonları ile karşılaştırıldığında Türkiye'deki örgüt yapılanmalarının görev, yetki ve etkinliklerinin kısıtlı kaldığı gözlenmektedir.

OPD altında yer alan ve ürünün pazarlanmasını önemli şekilde etkileyen tüketici bilgilendirmesine yönelik hazırlanan etiketleme hükümleri ülkemizde de kısmi olarak uygulamaktadır. Bu kapsamda su ürünleri yetiştiricilik ürünleri, 'Türk Gıda Kodeksi Gıda Etiketleme ve Tüketicileri Bilgilendirme Yönetmeliği (2017)'ne göre, uygulanmakta olan etiketleme hükümlerine uygun şekilde piyasaya sunulmak zorundadır. Ancak son yillarda etiketleme ve izlenebilirlik konularında ülkemizde birçok olumlu gelişme sağlanmış olmakla birlikte $\mathrm{AB}$ pazarındaki standartlara göre hala eksikliklerin olduğu söylenebilir. AB'de OPD altında yer alan ortak piyasa standartları piyasadaki sürdürülebilir ürün arzı, iç piyasanın dengesi, adil bir piyasa rekabeti ve ürün karlılığının artması açısından oldukça önemli görülmektedir. 1380 sayılı Su Ürünleri Kanun'u piyasadaki ürünler için bu tarz kapsamlı bir standart getirmemektedir. Bu nedenle 2012 Yilında 'Hayvansal Gıdalar İçin Özel Hijyen Kuralları Yönetmeliği’ne dayanılarak hazırlanmış olan '2012/73 sayılı Balıkçılık Ürünlerine Ait Duyusal Özellikler ve Toplam Uçucu Bazik Azot Limitleri Tebliği (2012)'ne göre piyasada yer alacak olan su ürünlerinin çeşitli standartları karşı1lıyor olması gerekmektedir. Türkiye'de pazarda yer alacak ürünler için belirlenmiş olan bu standartlar ile AB'de birlik içerisinde uygulanmakta olan standartlar arasında kısmi bir uyum söz konusudur. Yeni OPD'nin alt başlıklarından olan rekabet kuralları ve pazar bilgisi konularında ise ülkemizde su ürünleri özelinde oluş̧urulmuş benzer bir yapılanma halen mevcut değildir.

$\mathrm{Bu}$ kapsamda $\mathrm{AB}$ ve Türkiye'deki su ürünleri yetiştiricilik sektörü, AB'nin OBP'nın reform sonrası yeniden düzenlenen mevzuatları ve bunların uygulamaya olan yansımaları açısından genel hatlarıyla karşılaştırıldığında iki yapı arasında mevzuat ve uygulamalar açısından birçok farklılık gözlenmektedir. Elde edilen veriler 1şığında ülkemiz su ürünleri yetiştiricilik sektörüne yönelik objektif bir değerlendirme yaptığımızda sektörünün güçlü ve zayıf yönleri, olası firsatlar ve tehditlerine yönelik olarak ortaya çıkan SWOT analizi değerlendirmesi Çizelge 4'deki gibidir.

Çizelge 4.Su ürünleri yetiştiricilik sektörü SWOT analizi.

Table 4. SWOT analysis of Turkey aquaculture sector.

\begin{tabular}{ll}
\hline GÜÇLÜ YÖNLERİ & ZAYIF YÖNLERİ
\end{tabular}

- Türkiye'nin iç suları ve denizleri ile su ürünleri yetiştiriciliği için uygun su alanlarına sahip olması

- Yüksek üretim hacmi ve potansiyele rağmen kişi başına düşen tüketim miktarının çok düşük olması

- Birçok farklı türün yetiştiriciliğinin yapılmasına olanak sağlayan ekolojik avantaj

- Su ürünleri yetiştiricilik sektörünün devlet tarafindan destekleniyor oluşu ve bu desteklerin yıllar içinde üretimden, ekipmana, tesislerin modernizasyonundan yeni teknolojilerin adaptasyonuna birçok farklı alana yönelik çeşitlik kazanması

- Mevcut durumda sahip olunan eğitimli iş gücü ve bu iş gücünün her geçen gün sektörde daha fazla yer alması

- Su ürünlerinin AB'ye ihraç edilen tek hayvansal gida olması ve ihracattaki önemi

- Araştırma ve geliştirme olanaklarının yıllar içerisinde artması ile yeni teknolojilerin ve uygulamaların sektöre kazandırılması

- Sektörün gelişmeye açık oluşu ve taşıdığı yüksek üretim ve ihracat potansiyeli

- Ülkemizdeki su ürünleri yetiștiriciliği ile ilgili mevcut sorunların çözülmesine ve sektörün geliştirilmesine yönelik bir plan dahilinde hazırlanmış, çözüm odaklı bir yaklaşımın belirlendiği stratejik bir planın eksikliği

- Su ürünleri piyasasının düzenlenmesine yönelik arz talep dengesini kuracak, ürünler için ortak standartlar getirecek, pazarı güçlendirecek piyasa düzenlemelerinin yetersizliği

- Su ürünleri yetiştiricilerine yönelik oluşturulmuş, üreticilerin tüm üretim faaliyetlerinde aktif olarak yer alacak, sektörün gelişimine katkıda bulunacak etkin bir örgütlenme yapılanmasının eksikliği

- Yetiştiricilik ürünlerinin pazarlanmasında yaşanan sorunları ortadan kaldırmaya yönelik oluşturulmuş bir pazarlama stratejisi eksikliği

- Yem, kalite yönetimi ve ürün pazarlaması gibi konularda ortaya çıkan maliyetlerin küçük işletmeler için yüksek olması

- Kurumsal yapıda yıllar içerisinde birçok düzenleme yapılmış olmasına rağmen idari prosedürlerin halen küçük işletmeler için bir sorun teşkil ediyor olması

- Güçlü bir pazar politikası oluşturacak, sektörün gelişmesine ve korunmasına olanak sağlayacak kapsamlı bir çerçeve kanun yapılanmasına ihtiyaç duyulması ve bu konuda 1380 sayılı mevcut $\mathrm{Su}$ Ürünleri Kanunu'nun kapsamının su ürünleri yetiştiricilik sektörünün günümüz ihtiyaçlarını karşılanmasında yetersiz kalıyor olması

- Su ürünleri yetiştiriciliğine dair kamuoyunda var olan olumsuz imajın sektöre olumsuz etkisi

\begin{tabular}{l}
\hline FIRSATLAR \\
- Su ürünleri yetiştiriciliği ürünlerinin güvenilir bir besin kaynağı \\
yaratması sebebiyle tüm dünyada olduğu gibi Türkiye'de de \\
öneminin giderek artıyor olması \\
- Yetiştiriciliği yapıllmaya başlanan birçok yeni türün, mevcut \\
pazarlar dışında yeni ve farklı pazarlar yaratma potansiyeli \\
- Türkiye için en önemli dış pazar konumunda olan AB'nin ithal \\
balığa olan ihtiyacı ve Türkiye'nin AB pazarında gücünün her geçen \\
gün artıyor olması \\
- AB uyum süreci kapsamında getirilen yeni düzenlemeler ile \\
standartlar ve uygulamalar konusunda sağlanmış olan gelişmeler \\
- Yeni teknolojilerin sektöre adaptasyonu ile ürün çeşitlendirme ve \\
katma değerli ürün üretimine yönelik artan potansiyel
\end{tabular}
TEHDİTLER

- İç pazardaki belirsizliklerin özellikle küçük ölçekli üreticileri olumsuz yönde etkilemesi

- Devlet desteklerinin ihracat sürecinde $\mathrm{AB}$ tarafından ülkemize uygulanabilecek olası vergi uygulamalarına sebep olması ihtimali

- Bilinçsiz olarak gerçekleştirilen sanayi ve tarım faaliyetlerinin su kaynaklarına ve kalitesine verebileceği zararlar

- Su ürünleri yetiştiriciliğinde kullanılan bazı yemlerin fiyatlarının döviz kurları sebebiyle artması 
Sektörün yüksek üretim potansiyeli, gelişmesine yönelik her geçen gün daha kapsamlı şekilde devlet tarafından destekleniyor olması, AB uyum süreci kapsamında çıkarılmış olan yeni yasalarla birlikte ürün standartları ve üretim süreçleri konusunda kat edilen yol, bunların diş pazarlara açılmada sağladığı avantaj ve diş ticarete yönelik olumlu etkisi genel hatlarıyla ülkemizdeki mevcut durumun güçlü yönleri olarak karşımıza çıkmaktadır. Ancak üretim sürecindeki bu olumlu tablo piyasanın düzenlenmesi ve pazarlama süreçleri söz konusu olduğunda değişmektedir. AB'de güçlü bir piyasa yapılanması adına oluşturulmuş kapsamlı bir OPD tüzüğü mevcuttur. Ülkemizdeki düzenlemeler incelendiğinde ise su ürünleri yetiştiriciliğine yönelik oluşturulmuş güçlü bir pazar politikasından söz etmek mümkün değildir. Bu eksiklik özellikle pazarlamaya yönelik sorunları da beraberinde getirmektedir. Bu durum ülkemiz politikaları açısından zayıf bir yön olarak karşımıza çıkmaktadır. Pazarlama kanalarında yaşanan sorunlar, pazar için hazırlanan ürünlerle ilgili ortak standartların ve fiyat politikasının belirlenerek hem üreticiyi hem de tüketiciyi koruyacak ortak bir pazarlama stratejisinin eksikliği pazar açısından bir sorun oluşturmaktadır. Yine benzer şekilde üreticilerin birlikte hareket etmesine olanak sağlayan ve böylelikle sektörün gelişmesine önemli katkılarda bulunan örgütlenme yapılarına yönelik düzenlemelerin de ülkemiz politikalarında gerektiği şekilde kapsamlı olmadığ 1 görülmektedir. Sektörün gücünü artıracak bir pazar politikası eksikliği yüksek üretim potansiyelinin istenilen oranda bir ekonomik değere dönüşememesi açısından önemli bir tehdit oluşturmaktadır. AB pazarının ithal balığa olan ihtiyacı ve ülkemizin bu talebi karşılayabilecek kaliteli ürün kapasitesine sahip olması, bunun yanı sıra ülkemizde birçok farklı türün yetiştiriciliğinin yapılmasına olanak veren ekolojik avantaj sektörün genişlemesi açısından önemli firsatlar yaratmaktadır. Ancak firsatları en etkin şekilde değerlendirebilmek için güçlü bir pazar politikasına da ihtiyaç vardır. Ayrıca sektörün bu anlamda güçlenmesi hem üreticinin hem de tüketicinin iç pazardaki ekonomik dalgalanmalardan etkilenmesi riskini de en aza indirecek önemli bir tedbir olarak görülmektedir. Yukarıda bahsi geçen tüm durumlar göz önüne alınarak sektöre yönelik hazırlanacak kapsamlı ve çözüm odaklı stratejik bir gelişim planının sektöre çok önemli faydalar sağlayacağı düşünülmektedir.

\section{Sonuç}

Çalışma sonucunda ortaya çıkan verilerinde ortaya koyduğu gibi gerek üretim miktarları gerekse yetiştiriciliğin taşıdığı yüksek potansiyel ülkemiz su ürünleri yetiştiricilik sektörünün mevcut gelişiminin gelecekte de devam edeceğini göstermektedir. Ancak, yapılan araştırmadan da anlaşılacağ üzere Türkiye'deki su ürünleri yetiştiricilik sektörünün birçok temel konuda halen eksikleri mevcuttur. Bunun yanı sıra eksik ve yanlış bilgilendirme sebebiyle su ürünleri yetiştiricilik sektörüne yönelik kamuoyunda olumsuz bir imajın varlığı söz konusudur. Ancak sektördeki tüm bu olumsuzlukların giderilmesi için alınabilecek birçok tedbir bulunmaktadır. Bu tedbirlerin başında doğal kaynaklarımızın doğru kullanılmasına olanak sağlayacak ve sektörün güçlendirilmesine yönelik düzenlemeleri getirecek, sürdürülebilirliği temel almış olan yeni bir su ürünleri politikasının oluşturulması gelmektedir. Bu kapsamda pazar için hazırlanan ürünlerle ilgili ortak bir standardın ve fiyat politikasının belirlenmesi, sağlanacak olan adil bir pazar rekabeti, sektörün geleceği açısından oldukça önemli görülmektedir. Yine bir diğer önemli konu olan örgütlenme yapılarıyla ilgili su ürünleri kooperatiflerinin ve su ürünleri üretici birliklerinin sektör içinde daha etkili hale getirilecek şekilde konumlandırılması, gerekli düzenleme ve kontrollerin yapıllyor olması önemlidir. Bunun yanı sira üreticilerin üretmiş oldukları ürünlerini etkin şekilde pazarlanmasına olanak sağlayacak, ülke çapında oluşturulmuş bir pazarlama stratejisi, sektörde su ürünlerinin pazarlanmasındaki mevcut eksikliklerin ve sorunların giderilmesini sağlayarak hem iç pazarın güçlendirilmesi hem de dış pazardaki rekabet edilebilirliğin artırılmasına önemli bir katkıda bulunacaktır. $\mathrm{Bu}$ kapsamda mevzuattaki yeni düzenlemelerin uygulamaya geçirilmesinin; $\mathrm{AB}$ başta olmak üzere, dünyada su ürünleri yetiştiriciliği konusunda ilerlemiş olan ülkelerin pazarlarındaki son eğilimlerin takip edilmesi önemlidir. Çalışmanın başında da belirtildiği gibi Türkiye gerek sahip olduğu denizel alanlar gerekse zengin iç suları ile su ürünleri yetiştiriciliği için verimli kaynaklara sahip bir ülkedir. Ülkemizdeki mevcut su ürünleri üretimi bugün $A B$ üye ülkeleri arasında yer alan birçok ülkenin üretim miktarlarından çok daha yüksek seviyelerde gerçekleşmektedir. Bu nedenle sektöre yönelik iyileştirici tedbirlerin alınması, doğru tanıtım stratejileri ve çeşitli mevzuatların yeniden düzenlenmesiyle birlikte Türkiye'deki su ürünleri yetiştiricilik sektörünün çok daha güçlü bir sektör haline geleceği düşünülmektedir.

\section{Kaynaklar}

Balıkçılık Ürünlerine Ait Duyusal Özellikler ve Toplam Uçucu Bazik Azot Limitleri Tebliği (2012) Tebliğ No: 2012/73 https://www.resmigazete.gov.tr/eskiler/2012/11/20121121-11.htm. Erişim 12 Eylül 2019.

Çavdar Y (2009) Su Ürünleri Yetiştiriciliğinde Desteklemeler. SÜMAE Yunus Araştırma Bülteni 1(1): 13-14.

EU Market Report (2018) The EU Fish Market 2017 Edition. http://www.eumofa.eu/. Accessed 04 May 2019.

EU Regulation (2002) Regulation (EC) No 178/2002 of the European Parliament and of the Council of 28 January 2002 laying down the general principles and requirements of food law, establishing the European Food Safety Authority and laying down procedures in matters of food safety / Official Journal L 031, 01/02/2002 P. 0001 0024. https://eur-lex.europa.eu/legalcontent/EN/TXT/?uri=celex\%3A32002R0178. Accessed 12 March 2019.

EU Regulation (2013) Regulation (Eu) No 1379/2013 Of The European Parliament and of the Counc1l of 11 December 2013 on The Common Organization of the Markets in Fishery and Aquaculture Products. https://eur-lex.europa.eu/legalcontent/EN/TXT/?uri=celex\%3A32013R1379. Accessed 04 May 2019.

EU Regulation (2014a) Regulation (Eu) No 1380/2013 Of The European Parliament and of the Council of 11 December 2013 on the Common Fisheries Policy. https://eur-lex.europa.eu/legalcontent/EN/TXT/?uri=CELEX\%3A32013R1380. Accessed 21 May 2019.

EU Regulation (2014b) Regulation (Eu) No 508/2014 of the European Parliament and of the Council of 15 May 2014 on the European Maritime and Fisheries Fund. https://eur-lex.europa.eu/legalcontent/EN/TXT/?uri=CELEX\%3A32014R0508. Accessed 12 May 2019.

EUMOFA (2019) EUMOFA Seabass in the EU case study. Accessed 12 September 2019.

European Commission (2011) Communication from the Commission to the European Parliament, the Council, the European Economic and Social Committee and The Committee of the Regions Reform of the Common Fisheries Policy . /* COM/2011/0417 final */ Section1. 
lex.europa.eu/legalcontent/EN/TXT/?uri=CELEX:52011DC0417. Accessed 12 September 2018.

European Commission (2013) Communication from the Commission to the European Parliament, the Council, the European Economic and Social Committee and the Committee of the Regıons Strategic Guidelines for the Sustainable Development of Eu Aquaculture /* Com/2013/0229 Final. / https://eur-lex.europa.eu/legalcontent/EN/TXT/?uri=CELEX\%3A52013DC0229. Accessed 25 March 2018.

European Commission (2014a) European Commission 'European Maritime and Fisheries Fund'. https://ec.europa.eu/fisheries/cfp/emff_en. Accessed 19 April 2018.

European Commission (2014b) European Commission 'market'. https://ec.europa.eu/fisheries/cfp/market. Accessed 16 May 2019.

European Commission (2016) Summary of the 27 Multiannual National Aquaculture Plans file online. https://ec.europa.eu/fisheries/sites/fisheries/files/docs/body/27multiannual-national-aquaculture-plans-summary_en.pdf. Accessed 05 April 2019.

Kooperatifler Kanunu (1969) Resmi Gazete, 13195, 24 Nisan 1969. http://www.mevzuat.gov.tr/MevzuatMetin/1.5.1163.pdf. Erişim 18 Mayis 2019.

Su Ürünleri Kanunu (1971) Resmi Gazete, 13799, 4 Nisan 1971. https://www.tbmm.gov.tr/tutanaklar/KANUNLAR KARARLAR/k anuntbmmc054/kanuntbmmc054/kanuntbmmc05401380.pdf. Erişim 20 Mayıs 2019.

$\mathrm{Su}$ Ürünleri Yetiștiriciliği Destekleme Tebliği (2018) Tebliğ No: 2018/24. http://www.resmigazete.gov.tr/eskiler/2018/05/20180529. 19.htm. Erişim 08 Nisan 2019.

Su Ürünleri Yetiştiriciliğinde İyi Tarım Uygulamaları Destekleme
Ödemesi Yapılmasına Dair Tebliğ (2019) Tebliğ No: 2019/11 http://www.resmigazete.gov.tr/eskiler/2019/02/20190210-3.htm. Erişim 09 Mart 2019.

T.C. Ziraat Bankası A.S. ve Tarım Kredi Kooperatiflerince Tarımsal Üretime Dair Düşük Faizli Yatırım ve İşletme Kredisi Kullandırılmasına İlişkin Uygulama Esasları Tebliği (2018) Tebliğ No: 2018/16 http://www.resmigazete.gov.tr/eskiler/2018/03/20180316-18.htm. Erișim 12 Nisan 2019.

$\begin{array}{llll}\text { Tarım } & \text { Sigortalar1 } & \text { Kanunu } & \text { (2005) }\end{array}$ Haziran2005.http://www.resmigazete.gov.tr/eskiler/2005/06/20050 621-2.htm. Erişim 11Nisan 2019.

Tarımsal Üretici Birlikleri Kanunu (2004) Resmi Gazete, 25514, 29 Haziran

2004 http://www.mevzuat.gov.tr/MevzuatMetin/1.5.5200.pdf. Erişim 10 May1s 2019.

TKDK (2019) Tarım ve Kırsal Kalkınmayı Destekleme Kurumu. https://www.tkdk.gov.tr/. Erişim 11 Mayıs 2019.

TÜİK (2019) Su Ürünleri İstatistikleri. Türkiye İstatistik Kurumu, http://tuik.gov.tr. Erişim 24 Mayıs 2019.

Türk Gıda Kodeksi Gıda Etiketleme ve Tüketicileri Bilgilendirme Yönetmeliği (2017) ResmiGazete,29960 (Mükerrer)26Ocak2017.http://www.resmigazet e.gov.tr/eskiler/2017/01/20170126M1-6.htm. Erişim 22 Nisan 2019.

Veteriner Hizmetleri, Bitki Sağlığı, Gıda ve Yem Kanunu (2010) Resmi Gazete, 27610, Haziran 2010. http://www.resmigazete.gov.tr/eskiler/2010/06/20100613-12.htm. Erişim 02 Mayıs 2019. 